\title{
Continuous Cultivation of Photosynthetic Bacteria for Fatty Acids Production
}

Kim, Dong-Hoon ; Lee, Ji-Hye; Hwang, Yuhoon; Kang, Seoktae; Kim, Mi-Sun

Published in:

Bioresource Technology

Link to article, DOI:

10.1016/j.biortech.2013.08.078

Publication date:

2013

Link back to DTU Orbit

Citation (APA):

Kim, D-H., Lee, J-H., Hwang, Y., Kang, S., \& Kim, M-S. (2013). Continuous Cultivation of Photosynthetic Bacteria for Fatty Acids Production. Bioresource Technology, 148, 277-282.

https://doi.org/10.1016/j.biortech.2013.08.078

\section{General rights}

Copyright and moral rights for the publications made accessible in the public portal are retained by the authors and/or other copyright owners and it is a condition of accessing publications that users recognise and abide by the legal requirements associated with these rights.

- Users may download and print one copy of any publication from the public portal for the purpose of private study or research.

- You may not further distribute the material or use it for any profit-making activity or commercial gain

- You may freely distribute the URL identifying the publication in the public portal

If you believe that this document breaches copyright please contact us providing details, and we will remove access to the work immediately and investigate your claim. 


\section{Accepted Manuscript}

Continuous Cultivation of Photosynthetic Bacteria for Fatty Acids Production

Dong-Hoon Kim, Ji-Hye Lee, Yuhoon Hwang, Seoktae Kang, Mi-Sun Kim

PII:

S0960-8524(13)01308-4

DOI: http://dx.doi.org/10.1016/j.biortech.2013.08.078

Reference: BITE 12277

To appear in:

Bioresource Technology

Received Date:

14 May 2013

Revised Date:

10 August 2013

Accepted Date:

14 August 2013

Please cite this article as: Kim, D-H., Lee, J-H., Hwang, Y., Kang, S., Kim, M-S., Continuous Cultivation of Photosynthetic Bacteria for Fatty Acids Production, Bioresource Technology(2013), doi: http://dx.doi.org/10.1016/ j.biortech.2013.08.078

This is a PDF file of an unedited manuscript that has been accepted for publication. As a service to our customers we are providing this early version of the manuscript. The manuscript will undergo copyediting, typesetting, and review of the resulting proof before it is published in its final form. Please note that during the production process errors may be discovered which could affect the content, and all legal disclaimers that apply to the journal pertain. 


\title{
Continuous Cultivation of Photosynthetic Bacteria for Fatty
}

\section{Acids Production}

Dong-Hoon Kim ${ }^{\mathrm{a}}$, Ji-Hye Lee ${ }^{\mathrm{a}}$, Yuhoon Hwang ${ }^{\mathrm{b}, \mathrm{c}}$, Seoktae Kang ${ }^{\mathrm{d}}$, Mi-Sun Kim ${ }^{\mathrm{a}, \mathrm{e}}$

${ }^{a}$ Clean Fuel Department, Korea Institute of Energy Research, 102 Gajeong-ro, Yuseong-gu, Daejeon 305-343, Republic of Korea

${ }^{\mathrm{b}}$ Department of Environmental Engineering, Technical University of Denmark, Miljøvej, Bygning 113, DK-2800 Kgs. Lyngby, Denmark

${ }^{c}$ Korea Advanced Institute of Science and Technology, 373-1, Guseong-dong, Yuseong-gu, Daejeon 305-701, Republic of Korea

${ }^{\mathrm{d}}$ Department of Civil Engineering, Kyung Hee University, 1732 Deokyoungdaero, Giheung, Yongin, Gyeonggi-do, 446-701, Republic of Korea

${ }^{\mathrm{e}}$ Division of Renewable Energy Engineering, University of Science and Technology, 217 Gajeong-ro, Yuseong-gu, Daejeon 305-350, Republic of Korea

*Corresponding author: Mi-Sun Kim (E-mail address: bmmskim@kier.re.kr, Tel: +82-42860-3554; fax: +82-42-860-3739)

\begin{abstract}
In the present work, we introduced a novel approach for microbial fatty acids (FA) production. Photosynthetic bacteria, Rhodobacter sphaeroides KD131, were cultivated in a
\end{abstract}


continuous-flow, stirred-tank reactor (CFSTR) at various substrate (lactate) concentrations. At hydraulic retention time (HRT) $4 \mathrm{~d}$, cell concentration continuously increased from $0.97 \mathrm{~g}$ $\mathrm{dcw} / \mathrm{L}$ to $2.05 \mathrm{~g} \mathrm{dcw} / \mathrm{L}$ as lactate concentration increased from $30 \mathrm{mM}$ to $60 \mathrm{mM}$. At $70 \mathrm{mM}$, however, cell concentration fluctuated with incomplete substrate degradation. By installing a membrane unit to CFSTR, a stable performance was observed under much higher substrate loading (lactate $100 \mathrm{mM}$ and HRT $1.5 \mathrm{~d}$ ). A maximum cell concentration of $16.2 \mathrm{~g} \mathrm{dcw} / \mathrm{L}$, cell productivity of $1.9 \mathrm{~g} \mathrm{dcw} / \mathrm{L} / \mathrm{d}$, and FA productivity of $665 \mathrm{mg} \mathrm{FA} / \mathrm{L} / \mathrm{d}$ were attained, and these values were comparable with those achieved using microalgae. The FA content of $R$. sphaeroides was around $35 \%$ of dry cell weight, mainly composed of vaccenic acid (C18:1, omega-7).

Keywords: photosynthetic bacteria; fatty acids; membrane-coupled bioreactor; lactate; cell productivity

\section{Introduction}

Environmental concerns, energy shortage, and consequent increasing energy costs have emphasized the need to produce sustainable and renewable fuels (Steen et al., 2010). To this end, huge effort is now being focused on the production of lipids using microalgae (Chen et al., 2011). Under unfavourable culture conditions, they are able to store neutral lipids, 20$70 \%$ of their body in heterotrophic or autotrophic ways, mainly in the form of triacylglycerol (TAG). TAG is convenient storage compound for carbon and energy, possessing high calorific value, and can be used as industrial chemical and bioenergy feedstock (Alvarez et al., 2002). 
On the other hand, although photosynthetic bacteria do not accumulate neutral lipids, they are able to synthesize fatty acids, principally for glycerol-based membrane lipids (Carlozzi et al., 2010). The oil content (20-40\% of dry biomass weight) of photosynthetic bacteria is generally lower than that of microalgae, and therefore, the research on this subject has been scarce. However, they are simpler to cultivate than microalgae that they do not require stressful environments for lipids production. In addition, bacteria are much more genetically manipulatable than algae. The expression of specific genes could result in the overproduction of fatty acids and their secretion to the broth (Steen et al., 2010). Until now, the use of purple non-sulfur phototrophic bacteria has been proposed mainly for the production of hydrogen and polyhydroxybutyrate (PHB), as well as for wastewater treatment (Khatipov et al., 1998; Kim et al., 2006; Wu et al., 2012). Electrons contained in organic materials can be released as hydrogen by nitrogenase with the help of light energy, and PHB is formed when PNS bacteria are faced with a suboptimal environment. Recently, the co-production of hydrogen and lipids under anaerobic conditions was suggested (Carlozzi et al., 2010). During the cultivation of Rhodopseudomonas palustris under anaerobic light conditions, lipid content of 22-39\% of dry biomass weight was observed. However, this study was limited to batch operation: it is important to maximize the lipid productivity by continuous operation. In addition, the effective use and design of a continuous culture are known to lower the production cost (Chen et al., 2011).

During the production of photosynthetic bacteria in a continuous culture system, the ability to maintain a balanced concentration of chemical substances and cells is critical to obtain higher productivity than in a batch culture system. However, there are many difficulties in maintaining a continuous culture for long periods without mutation and microbial 
contamination. Population changes due to mutation or microbial contamination in the pure culture of a microbial strain have frequently been reported in continuous culture systems (Toda, 2003).

The use of a membrane-coupled bioreactor has recently gained recognition as a solution to the above problems by decreasing contamination risks and cleaning frequencies, and by higher cell concentration compared to a standard stirred tank bioreactor (Glazyrina et al., 2010). In addition, it is possible to reuse the water and nutrients in the permeate from the membrane filter by retaining cells that are larger than the diameter of membrane pore. Recent works employing various microorganisms immobilized in membrane-based culture systems have shown that extremely high, sludge-like densities of ca. $10^{12}$ cells per ml were possible in such systems and that the productivity of membrane reactors continues at high levels for more than two weeks (Lee et al., 2008; Ríos et al., 2012).

In this study, we suggested a novel approach for microbial fatty acids production, which is competitive with a traditional way of using microalgae. Photosynthetic bacteria, Rhodobacter sphaeroides KD131, were cultivated for fatty acids production using lactate as a substrate. Organic acids that mostly consisted of lactate can be easily obtained from fermentation products in agricultural and food waste (Kim et al., 2009). To maximize the cell productivity, a continuous-flow, stirred-tank reactor (CFSTR) was operated at various substrate concentrations and hydraulic retention times (HRT). A membrane unit was installed in the CFSTR for further increase of cell concentration and productivity. To our knowledge, this is the first attempt to apply the concept of a membrane-coupled bioreactor aiming at continuous cell harvesting. In addition, the fatty acids profile of the bacteria was assayed and the performance obtained in this study was compared with that using microalgae. 


\section{Methods}

\subsection{Inoculum preparation}

The phototropic bacterium $R$. sphaeroides KD131 isolated from mudflats along the coast of Daebu Island in the West Sea of South Korea was cultivated for fatty acids production (Kim and Kim, 2012). The KD131 strain was pre-cultured in a modified Sistrom's broth (Kim et al., 2012) containing $4 \mathrm{mM}\left(\mathrm{NH}_{4}\right)_{2} \mathrm{SO}_{4}, 0.3 \mathrm{mM} \mathrm{L}$-aspartic acid, and $20 \mathrm{mM}$ lactate at $30^{\circ} \mathrm{C}$ for $24 \mathrm{hr}$ under $54 \mathrm{~W} / \mathrm{m}^{2}$ irradiance using a halogen lamp (12V, 50W).

\subsection{Reactor operation}

A 1.2 L glass reactor (effective volume of $1.0 \mathrm{~L}, 200 \mathrm{~mm}$ high by $80 \mathrm{~mm}$ diameter) installed with a membrane unit was designed for the continuous cultivation of $R$. sphaeroides (Fig. 1). Three halogen lamps were properly located to adjust the light intensity at $54 \mathrm{~W} / \mathrm{m}^{2}$ on the reactor wall. The membranes are made of high density polyethylene (HDPE) with a normal pore size of $0.4 \mu \mathrm{m}$ and an effective filtration area of $0.006 \mathrm{~m}^{2}$. A certain amount of centrifuged microorganism was inoculated to reach an initial cell concentration of $0.5 \mathrm{~g}$ dcw/L. After purging with Ar gas for $1 \mathrm{hr}$, the reactor was operated for $48 \mathrm{hr}$ by batch mode, and then switched to a continuous mode. It was agitated using a magnetic stirrer at $150 \mathrm{rpm}$. Feedstock contained $30 \mathrm{mM}$ of lactate with nutrient medium as mentioned above. All experiments were conducted in a constant temperature room at $30 \pm 1^{\circ} \mathrm{C}$.

First, the reactor was operated by a CFSTR mode (w/o membrane unit operation). Lactate concentration was gradually increased from $30 \mathrm{mM}$ to $70 \mathrm{mM}$ at a fixed HRT $4 \mathrm{~d}$. As the performance failure was observed at $70 \mathrm{mM}$, lactate concentration was decreased to $40 \mathrm{mM}$, and the reactor was operated as membrane-coupled bioreactor mode. Once a day, $50 \mathrm{~mL}$ of 
cell broth, which was harvested for fatty acids production, was pulled out corresponding to a cell retention time (CRT) of $20 \mathrm{~d}$, while HRT was kept at $4 \mathrm{~d}$. In order to increase substrate loading, first, substrate concentration was gradually increased up to $120 \mathrm{mM}$. Afterwards, HRT was gradually shortened to $1 \mathrm{~d}$ at a fixed lactate concentration of $100 \mathrm{mM}$. The CRT/HRT ratio was kept at 5. Permeation of membranes was continuously maintained by using a peristaltic pump according to the HRT. One cycle of membrane filtration consisted of 45 min of filtration and 15 min of releasing. In order to reach the steady-state and to obtain average performance values, the reactor was operated for more than five times of HRT at each operating condition.

\subsection{Analysis}

Residual lactate was analyzed by a high performance liquid chromatograph (HPLC) (Finnigan Spectra SYSTEM LC, Thermo Electron Co.) with an ultraviolet (210 nm) detector (UV1000, Thermo Electron) and an $100 \mathrm{~mm} \times 7.8 \mathrm{~mm}$ Fast Acid Analysis column (Bio-Rad Lab.) using $0.005 \mathrm{M} \mathrm{H}_{2} \mathrm{SO}_{4}$ as mobile phase. The liquid samples were pretreated with a 0.45 $\mu \mathrm{m}$ membrane filter before injection to both HPLCs. Cell concentration and fatty acids were measured according to the methods described in Kim et al. (2012) and Carlozzi et al. (2010), respectively.

\section{Results and Discussion}

\subsection{CFSTR performance}

High substrate concentration allows energy-efficient operation and results in concentrated biomass unless substrate inhibition occurs. In microbial oil production, in particular, a high 
level of biomass concentration is essential for the ease of downstream processing such as harvesting, dewatering, and extracting (Chen et al., 2010).

Fig. 2 shows the daily performance of CFSTR in terms of cell concentration and lactate degradation at HRT $4 \mathrm{~d}$. As lactate concentration increased from $30 \mathrm{mM}$ to $60 \mathrm{mM}$, cell concentration continuously increased from $0.97 \mathrm{~g} \mathrm{dcw} / \mathrm{L}$ to $2.05 \mathrm{~g} \mathrm{dcw} / \mathrm{L}$. The experimental period used to obtain average performance values are shown in Table 1. At $70 \mathrm{mM}$, however, cell concentration started to fluctuate with incomplete substrate degradation, suggesting substrate inhibition. At similar substrate strength, the inhibition has been observed in the continuous culture of heterotrophic microalgae and photosynthetic bacteria (Chen and Johns 1996; Xie et al., 2012). In the CFSTR operation of $R$. sphaeroides fed with lactate at HRT $4 \mathrm{~d}$, the highest cell concentration of $2.05 \mathrm{~g} \mathrm{dcw} / \mathrm{L}$ and cell productivity of $0.54 \mathrm{~g} \mathrm{dcw} / \mathrm{L} / \mathrm{d}$ were obtained at $60 \mathrm{mM}$. Cell productivity was calculated by dividing cell concentration to the corresponding CRT.

It appears that cell yield, the conversion ratio of input substrate to cell growth, was constant at around 50\%, although the substrate concentration changed. Cell yield was calculated by assuming the composition of $\mathrm{C}_{5} \mathrm{H}_{7} \mathrm{O}_{2} \mathrm{~N}$, resulting in a chemical oxygen demand (COD) value of $1.42 \mathrm{~g} \mathrm{COD} / \mathrm{g} \mathrm{dcw}$ (Kim et al., 2012). The reported cell yield of photosynthetic bacteria varied as $20-70 \%$ depending on the carbon sources, nutrient composition, and operational parameters such as pH and HRT (Kim et al., 2012; Yilmaz et al., 2010). 50\% cell yield meant that half of the electrons contained in the substrate were used for cell growth while remaining electrons were converted to other metabolites such as soluble microbial products (SMPs). SMPs are defined as soluble organic compounds produced during substrate metabolism and biomass decay and they have been important research topics in biological wastewater 
treatment for more than two decades (Laspidou and Rittmann, 2002). However, it was only recently recognized in the field of using photosynthetic bacteria that SMPs have a sizable impact on the electron distribution (Kim et al., 2012; Yilmaz et al., 2010). Further researches on SMP issue such as formation mechanisms, characteristics, and metabolic and genetic control strategies are needed to increase the cell yield.

\subsection{Membrane-coupled bioreactor performance - Effect of substrate concentration}

In the concept of a membrane-coupled bioreactor, a complete retention of biomass by membrane process makes it possible to maintain a high biomass concentration, and thus, a stable performance under high substrate loading can be expected (Judd, 2008).

In this study, first, lactate concentration gradually increased from 40 to $100 \mathrm{mM}$ while the HRT and CRT were fixed at $4 \mathrm{~d}$ and $20 \mathrm{~d}$, respectively. The cell concentration gradually increased and reached $14.38 \mathrm{~g} \mathrm{dcw} / \mathrm{L}$ at $100 \mathrm{mM}$ (Fig. 3). Compared to the cell concentration in the CFSTR, this value was seven times higher, which could significantly reduce the cost in the downstreaming process (Table 2). To our knowledge, this is the highest cell concentration achieved to date in various application fields of photosynthetic bacteria. In photofermentative $\mathrm{H}_{2}$ production, cell concentration was maintained at a low level (generally $<3 \mathrm{~g}$ $\mathrm{dcw} / \mathrm{L})$ since light penetration is essential for the activation of nitrogenase, the central enzyme producing hydrogen (Pattanamanee et al., 2012). In wastewater treatment using photosynthetic bacteria, several attempts have been made to increase cell concentration, but the result was less than $5 \mathrm{~g}$ dcw/L (Kaewsuk et al., 2010).

The reactor performance significantly dropped immediately after increasing lactate concentration to $120 \mathrm{mM}$ with incomplete lactate degradation. It seemed that $R$. sphaeroides 
could not be adapted at this high substrate concentration and the cell concentration decreased by the pullout of biomass for CRT control. To recover the performance, lactate concentration decreased to $100 \mathrm{mM}$ at further operation.

\subsection{Membrane-coupled bioreactor performance - HRT and CRT control}

Although high cell concentration was achieved by installing a membrane unit, cell productivity was only increased by $30 \%$ compared to the reactor performance without membrane, due to long CRT of $20 \mathrm{~d}$ ( $4 \mathrm{~d}$ for reactor without membrane). The way to increase cell productivity is to reduce CRT while increasing the substrate loading. As larger amount of biomass is removed from the reactor at short CRT, more substrate should be supplied to maintain the biomass concentration in the reactor. From the 193th day, HRT and CRT were gradually shortened to $1 \mathrm{~d}$ and $5 \mathrm{~d}$, respectively, while keeping the CRT/HRT ratio at 5 , meaning that the same amount of substrate was supplied to keep the biomass concentration unless the cell yield changed.

As HRT and CRT gradually shortened to $2 \mathrm{~d}$ and $10 \mathrm{~d}$, respectively, both cell concentration and cell productivity increased up to $16.20 \mathrm{~g} \mathrm{dcw} / \mathrm{L}$ and $1.62 \mathrm{~g} \mathrm{dcw} / \mathrm{L} / \mathrm{d}$, respectively (Fig. 2, Table 2). As the CRT/HRT ratio was kept at the same substrate concentration, the increased cell concentration indicates the increased cell yield. In the application of membrane-coupled bioreactor, high cell yield has generally been observed under short CRT (Duan et al., 2009; Huang et al., 2001). At HRT $1.5 \mathrm{~d}$ and CRT $7.5 \mathrm{~d}$, the cell concentration decreased to $14.29 \mathrm{~g}$ dcw/L with a small amount of lactate remaining. However, the overall mass of cultivated biomass was enhanced to $1.90 \mathrm{~g}$ dcw/L/d, which was 3.5 times higher than that in the CFSTR operation. Further decrease of HRT and CRT to $1 \mathrm{~d}$ and $5 \mathrm{~d}$, respectively, caused the failure 
of reactor operation. Moreover, the trans membrane pressure (TMP), which was maintained less than $20 \mathrm{kPa}$ during the previous operation, increased up to $30 \mathrm{kPa}$. Because of membrane fouling, it was impossible to continue the reactor operation. The flux could be calculated based on the effective surface area of membrane module, $0.006 \mathrm{~m}^{2}$. The calculated flux at HRT $4,2,1.5$, and $1 \mathrm{~d}$ are $1.74,3.47,4.65$, and $6.94 \mathrm{~L} / \mathrm{m}^{2} / \mathrm{h}$, respectively. The significant increase of TMP was not observed during the operation periods under the HRT 4 to 1.5 days, but the significant membrane fouling was occurred at right after reactor operation under the HRT $1 \mathrm{~d}$.

Using the stepwise increase of flux, the critical flux could be obtained. Critical flux is a criterion for the transition between concentration polarization and fouling. The critical flux is reached when irreversible fouling occurs locally on the membrane (Bacchin, 2004). The reactor was operated under an intermittent filtration regime (45 min filtration/15 min pause), and no irreversible fouling was observed under the flux of $1.74-4.65 \mathrm{~L} / \mathrm{m}^{2} / \mathrm{h}$. On the other hand, a significant increase of TMP was observed under the flux of $6.94 \mathrm{~L} / \mathrm{m}^{2} / \mathrm{h}$. Therefore, the critical flux for this membrane module and reactor system can be determined as 4.65 $\mathrm{L} / \mathrm{m}^{2} / \mathrm{h}$

\subsection{Fatty acids profile and the performance comparison}

The fatty acids profile of $R$. sphaeroides is shown in Fig. 4. During the membrane-coupled bioreactor operation, the microbial samples for fatty acid analysis were taken five times after reaching a steady-state at each substrate concentration, and the average values were obtained. The fatty acids content of $R$. sphaeroides investigated here was around 35\% of the dry cell weight, and did not vary according to the substrate concentration. Although some microalgae 
species can accumulate fatty acids over $50 \%$ of dry cell weight, it is obvious that $R$. sphaeroides are also suitable biomass resources for fatty acids generation. Ratledge and Wynn (2002) defined the microorganisms that can accumulate fatty acids at more than $20 \%$ of their body as oleaginous species. In addition, unlike phototrophic microalgae, dense cell cultivation was possible in the case of $R$. sphaeroides which was attributed their ability to capture every possible photon with high efficiency under light low intensity (Adams and Hunter, 2012). It is known that intracytoplasmic membranes (ICMs) containing structural components necessary for photosynthetic growth are developed when the light resource is limited.

The main fatty acid compositions of $R$. sphaeroides were $\mathrm{C} 16-\mathrm{C} 18$, which are appropriate for biodiesel production. In addition, the fatty acids from $R$. sphaeroides have special features in that they are mainly composed of unsaturated fatty acids whereas saturated forms are dominant in other microorganisms including microalgae, cyanobacteria, and Escherichia-coli (Chen et al., 2010; Lu, 2010; Steen et al., 2010). Saturated fatty acids have good oxidative stability, but poor fuel properties at low temperatures, which is a disadvantage in winter operation (Park et al., 2008). Also, unsaturated fatty acids are the raw materials for dietary supplements such as omega-3, omega-6, and omega-7 fatty acids. Vaccenic acid, comprising $60 \%$ of fatty acids of $R$. sphaeroides, is a main source of omega- 7 fatty acids, which has a crucial role in maintaining the health of skin and mucous membranes.

From the continuous cultivation of $R$. sphaeroides using the membrane-coupled bioreactor, maximum cell concentration of $16.2 \mathrm{~g} \mathrm{dcw} / \mathrm{L}$, cell productivity of $1.9 \mathrm{~g} \mathrm{dcw} / \mathrm{L} / \mathrm{d}$, and fatty acid productivity of $665 \mathrm{mg} \mathrm{FA} / \mathrm{L} / \mathrm{d}$ were attained, and these values were comparable with those achieved using microalgae (Table 3). Fatty acids productivity, representing the 
combined effects of fatty acid content and cell productivity, is a suitable index to indicate the effectiveness of a process (Chen et al., 2011). In the case of fatty acids production by photoautotrophic microalgae, continuous and pilot-scale operation has frequently been reported. The fatty acids productivity was in a range of 30-180 mg FA/L/d, which was comparably lower than that achieved in this study. On the other hand, higher cell productivity and fatty acids productivity have been reported in the heterotrophic microalgae cultivation. However, most of them were obtained from the batch operation.

In microalgae cultivation, the membrane has only been applied for the harvesting of cultured microalgae as an extracting process even though it has potential to integrate the cultivation and harvesting process together. In this study, the membrane-coupled bioreactor for cultivation and harvesting of photosynthetic bacteria was successfully operated continuously. The productivity of cells and fatty acids was higher than photoautotrophic microalgae and it was comparable with the microalgae production under heterotrophic conditions. It is suggested that the novel method developed here that is cultivating photosynthetic bacteria using membrane-coupled bioreactor could be an alternative way of microbial fatty acids production.

\section{Conclusions}

Photosynthetic bacteria, $R$. sphaeroides, were continuously cultivated for fatty acids production. By adopting a membrane-coupled bioreactor operation mode, a maximum cell concentration of $16.2 \mathrm{~g} \mathrm{dcw} / \mathrm{L}$, cell productivity of $1.9 \mathrm{~g} \mathrm{dcw} / \mathrm{L} / \mathrm{d}$, and fatty acids productivity of $665 \mathrm{mg} \mathrm{FA} / \mathrm{L} / \mathrm{d}$ were attained, which were comparable with those achieved using microalgae. The fatty acids content of $R$. sphaeroides was around 35\% of the dry cell weight 
with mainly composed of unsaturated fatty acids, in particular, vaccenic acid (C18:1, omega7). This work has high importance in the perspective of introducing a novel approach for microbial fatty acids production.

\section{Acknowledgements}

This work was supported by the Intelligent Synthetic Biology Center of Global Frontier Project funded by the Ministry of Education, Science and Tehcnology (2011-0031955) and also by Korea Institute of Energy Research.

\section{References}

1. Adams, P.G., Hunter, C.N., 2012. Adaptation of intracytoplasmic membranes to altered light intensity in Rhodobacter sphaeroides. BBA-Bioenergetics. 1817, 1616-1627.

2. Alvarez, H.M., Steinbuchel, A., 2002. Triacylglycerols in prokaryotic microorganisms. Appl. Microbiol. Biotechnol. 60, 637-376.

3. Bacchin, P., 2004. A possible link between critical and limiting flux for colloidal systems: consideration of critical deposit formation along a membrane. J. Mem. Sci. 228, $297-241$.

4. Carlozzi, P., Buccioni, A., Minieri, S., Pushparaj, B., Piccardi, R., Ena, A., Pintucci, C., 2010. Production of bio-fuels (hydrogen and lipids) through a photofermentation process. Bioresource Technol. 101, 3115-3120.

5. Chen, C.Y., Yeh, K.L., Aisyah, R., Lee, D.J., Chang, J.S., 2011. Cultivation, photobioreactor design and harvesting of microalgae for biodiesel production: A critical review. Bioresource Technol. 102, 71-81. 
6. Chen, F., Johns, M.R., 1996. Heterotrophic growth of Chlamydomonas reinhardtii on acetate in chemostat culture. Process Biochem. 31, 601-604.

7. Chiu, S.Y., Kao, C.Y., Chen, C.H., Kuan, T.C., Ong, S.C., Lin, C.S., 2008. Reduction of $\mathrm{CO}_{2}$ by a high-density culture of Chlorella sp. in a semicontinuous photobioreactor. Bioresource Technol. 99, 3389-3396.

8. Doucha, J., Straka, F., L1'vansky', K., 2005. Utilization of flue gas for cultivation of microalgae (Chlorella sp.) in an outdoor open thin-layer photobioreactor. J. Appl. Phycol. $17,403-412$.

9. Duan, L., Moreno-Andrade, I., Huang, C.L., Xia, S., Hermanowicz, S.W., 2009. Effects of short solids retention time on microbial community in a membrane bioreactor. Bioresource Technol. 100, 3489-3496.

10. Glazyrina, J., Materne, E.M., Dreher, T., Storm, D., Junne, S., Adams, T., Greller, G., Neubauer, P., 2010. High cell density cultivation and recombinant protein production with Escherichia coli in a rocking-motion-type bioreactor. Microb. Cell. Fact. 9, 42.

11. Graverholt, O.S., Eriksen, N.T., 2007. Heterotrophic high-cell-density fed-batch and continuous-flow cultures of Galdieria sulphuraria and production of phycocyanin. Appl. Microbiol. Biotechnol. 77, 69-75.

12. Huang, X., Gui, P., Qian, Y., 2001. Effect of sludge retention time on microbial behaviour in a submerged membrane bioreactor. Process Biochem. 36, 1001-1006.

13. Judd, S., 2008. The status of membrane bioreactor technology. Trends. Biotechnol. 26, 109-116.

14. Kaewsuk, J., Thorasampan, W., Thanuttamavong, M., Seo, G.T., 2010. Kinetic development and evaluation of membrane sequencing batch reactor (MSBR) with mixed 
cultures photosynthetic bacteria for dairy wastewater treatment. J. Environ. Manage. 91, $1161-1168$.

15. Kaiwan-arporn, P., Hai, P.D., Thu, N.T., Annachhatre, A.P., 2012. Cultivation of cyanobacteria for extraction of lipids. Biomass Bioenerg. 44, 142-149.

16. Khatipov, E., Miyake, M., Miyake, J., Asada, Y., 1998. Accumulation of poly- $\beta$ hydroxybutyrate by Rhodobacter sphaeroides on various carbon and nitrogen substrates. FEMS. Microbiol. Lett. 162, 39-45.

17. Kim, D.H., Kim, S.H., Shin, H.S., 2009. Hydrogen fermentation of food waste without inoculum addition. Enzym. Microb. Technol. 45, 181-187.

18. Kim, D.H., Son, H.N., Kim, M.S., 2012. Effect of substrate concentration on continuous photo-fermentative hydrogen production from lactate using Rhodobacter sphaeroides. Int. J. Hydrogen Energ. 37, 15483-15488.

19. Kim, M.S., Baek, J.S., Lee, J.K., 2006. Comparison of $\mathrm{H}_{2}$ accumulation by Rhodobacter spharoides KD131 and its uptake hydrogenase and PHB synthase deficient mutant. Int. J. Hydrogen Energ. 31, 121-127.

20. Laspidou, C.S., Rittmann, B.R., 2002. A unified theory for extracellular polymeric substances, soluble microbial products, and active and inert biomass. Wat. Res. 36, 27112720.

21. Lee, P.C., Lee, S.Y., Chang, H.N., 2008. Cell recycled culture of succinic acid-producing Anaerobiospirillum succiniciproducens using an internal membrane filtration system. J. Microbiol. Biotechnol. 18, 1252-1256. 
22. Liang, Y.N., Sarkany, N., Cui, Y., 2009. Biomass and lipid productivities of Chlorella vulgaris under autotrophic, heterotrophic and mixotrophic growth conditions. Biotechnol. Lett. 31, 1043-1049.

23. Lu, X., 2010. A perspective: Photosynthetic production of fatty acid-based biofuels in genetically engineered cyanobacteria. Biotechnol. Adv. 28, 742-746.

24. Pattanamanee, W., Choorit, W., Kantachote, D., Chisti, Y., 2012. Repeated-batch production of hydrogen using Rhodobacter sphaeroides S10. Int. J. Hydrogen Energ. 37, $15855-15866$.

25. Ratledge, C., Wynn, J.P., 2002. The biochemistry and molecular biology of lipid accumulation in oleaginous microorganisms. Adv. Appl. Microbiol. 51, 1-51.

26. Ríos, S.D., Salvadó, J., Farriol, X., Torras, C., 2012. Antifouling microfiltration strategies to harvest microalgae for biofuel. Bioresource Technol. 119, 406-418.

27. Park, J., Kim, D., Lee, J.P., Park, S.C., Kim, Y.J., Lee, J.S., 2008. Blending effects of biodiesels on xidation stability and low temperature flow properties. Bioresource Technol. 99, 3130-3135.

28. Rodolfi, L., Zittelli, G.C., Bassi, N., Padovani, G., Biondi, N., Bonini, G., Tredici, M.R., 2009. Microalgae for oil: Strain selection, induction of lipid synthesis and outdoor mass cultivation in a low-cost photobioreactor. Biotechnol. Bioeng. 102, 100-112.

29. Steen, E.J., Kang, Y., Bokinsky, G., Hu, Z., Schirmer, A., McClure, A., Cardayre, S.B., Keasling, J.D., 2010. Microbial production of fatty-acid-dervied fules and chemicals from plant biomass. Nature 463, 559-562.

30. Tang, H., Chen, M., Ng, K.Y., Salley, S.O., 2012. Continuous microalgae cultivation in a photobioreactor. Biotechnol. Bioeng. 109, 2468-2474. 
31. Toda, K., 2003. Theoretical and methodological studies of continuous microbial bioreactors. J. Gen. Appl. Microbiol. 49, 219-233.

32. Wu, P., Zhang, G., Li, J., Lu, H., Zhao, W., 2012. Effects of $\mathrm{Fe}^{2+}$ concentration on biomass accumulation and energy metabolism in photosynthetic bacteria wastewater treatment. Bioresource Technol. 119, 55-59.

33. Xie, G.J., Liu, B.F., Guo, W.Q., Ding, J., Xing, D.F., Nan, J., Ren, H.Y., Ren, N.Q., 2012. Feasibility studies on continuous hydrogen production using photo-fermentative sequencing batch reactor. Int. J. Hydrogen Energ. 37, 13689-13695.

34. Xiong, W., Li, X.F., Xiang, J.Y., Wu, Q.Y., 2008. High-density fermentation of microalga Chlorella protothecoides in bioreactor for microbio-diesel production. Appl. Microbiol. Biotechnol. 78, 29-36.

35. Yilmaz, L.S., Kontur, W.S., Sanders, A.P., Sohmen, U., Donohue, T.J., Noguera, D.R., 2010. Electron partitioning during light- and nutrient-powered hydrogen production by Rhodobacter sphaeroides. Bioenergy Res. 3, 55-66. 
Table 1 Average cell production performances at various substrate concentrations in the CFSTR

\begin{tabular}{cccccc}
\hline $\begin{array}{c}\text { Substrate } \\
\text { concentration } \\
(\mathrm{mM})\end{array}$ & $\begin{array}{c}\text { Data } \\
\text { acquired } \\
\left({ }^{\text {th }} \mathrm{day}\right)\end{array}$ & $\begin{array}{c}\text { Cell } \\
\text { concentration } \\
(\mathrm{g} \mathrm{dcw} / \mathrm{L})\end{array}$ & $\begin{array}{c}\text { Cell yield } \\
(\%)\end{array}$ & $\begin{array}{c}\text { Cell } \\
\text { productivity } \\
(\mathrm{g} \mathrm{dcw} / \mathrm{L} / \mathrm{d})\end{array}$ & $\begin{array}{c}\text { Lactate } \\
\text { degradation }\end{array}$ \\
\hline 30 & $6-27$ & $0.97 \pm 0.06$ & $47.6 \pm 1.9$ & $0.24 \pm 0.02$ & 99.7 \\
40 & $33-54$ & $1.39 \pm 0.04$ & $51.5 \pm 1.4$ & $0.35 \pm 0.01$ & 99.9 \\
50 & $58-79$ & $1.70 \pm 0.05$ & $50.4 \pm 1.5$ & $0.43 \pm 0.01$ & 99.7 \\
60 & $85-106$ & $2.05 \pm 0.10$ & $50.5 \pm 2.5$ & $0.51 \pm 0.01$ & 99.9 \\
\hline
\end{tabular}


Table 2 Average cell production performances at various operation conditions in the membrane-coupled bioreactor

\begin{tabular}{cccccc}
\hline $\begin{array}{c}\text { Substrate } \\
\begin{array}{c}\text { concentration } \\
(\mathrm{mM})\end{array}\end{array}$ & $\begin{array}{c}\text { HRT, SRT } \\
\text { (day) }\end{array}$ & $\begin{array}{c}\text { Data acquired } \\
\left({ }^{\text {th }} \text { day }\right)\end{array}$ & $\begin{array}{c}\text { Cell } \\
\text { concentration } \\
(\mathrm{g} \mathrm{dcw} / \mathrm{L})\end{array}$ & $\begin{array}{c}\text { Cell } \\
\text { productivity } \\
(\mathrm{g} \mathrm{dcw} / \mathrm{L} / \mathrm{d})\end{array}$ & $\begin{array}{c}\text { Lactate } \\
\text { degradation }\end{array}$ \\
\hline 40 & 4,20 & $19-41$ & $5.77 \pm 0.17$ & $0.29 \pm 0.01$ & 99.9 \\
60 & 4,20 & $49-81$ & $8.74 \pm 0.36$ & $0.44 \pm 0.22$ & 99.9 \\
80 & 4,20 & $91-122$ & $11.27 \pm 0.37$ & $0.57 \pm 0.01$ & 99.9 \\
100 & 4,20 & $134-162$ & $14.38 \pm 0.33$ & $0.72 \pm 0.02$ & 99.9 \\
& 3,15 & $210-232$ & $15.14 \pm 0.26$ & $1.01 \pm 0.02$ & 99.9 \\
& 2,10 & $248-272$ & $16.20 \pm 0.12$ & $1.62 \pm 0.01$ & 99.9 \\
& $1.5,7.5$ & $284-309$ & $14.29 \pm 0.29$ & $1.90 \pm 0.04$ & 97.2 \\
\hline
\end{tabular}


Table 3 Performance comparison of fatty acids productivity obtained in this study with microalgae

\begin{tabular}{|c|c|c|c|c|c|c|}
\hline $\begin{array}{l}\text { Cultivation } \\
\text { conditions }\end{array}$ & $\begin{array}{l}\text { Microbial } \\
\text { species }\end{array}$ & $\begin{array}{c}\text { Cell } \\
\text { productivity } \\
(\mathrm{g} \mathrm{dcw} / \mathrm{L} / \mathrm{d})\end{array}$ & $\begin{array}{l}\text { Fatty acids } \\
\text { content } \\
(\% \text { of } \mathrm{dcw})\end{array}$ & $\begin{array}{l}\text { Fatty acid } \\
\text { productivity } \\
\text { (mg FA/L/d) }\end{array}$ & $\begin{array}{c}\text { Reactor } \\
\text { and operation }\end{array}$ & Reference \\
\hline $\begin{array}{c}\text { Photo } \\
\text {-heterotroph }\end{array}$ & $\begin{array}{l}\text { Rhodobacter } \\
\text { sphaeroides }\end{array}$ & 1.9 & 35 & 665 & $\begin{array}{c}\text { Continuous (1 L) } \\
\text { (HRT } 1.5 \mathrm{~d}, \text { CRT } 7.5 \mathrm{~d})\end{array}$ & This study \\
\hline \multirow{6}{*}{$\begin{array}{c}\text { Photo } \\
\text {-autotroph }\end{array}$} & Chlorella sp. & 0.53 & 34 & 178.8 & Fed-batch $(0.8 \mathrm{~L})$ & $\begin{array}{l}\text { Chiu et al., } \\
2008\end{array}$ \\
\hline & Chlorella sp. & 3.8 & $\mathrm{~N} / \mathrm{A}^{\mathrm{a}}$ & $\mathrm{N} / \mathrm{A}^{\mathrm{a}}$ & $\begin{array}{l}\text { Fed-batch }(400 \mathrm{~L}) \\
\text { Flat plate type }\end{array}$ & $\begin{array}{c}\text { Doucha et al., } \\
2005\end{array}$ \\
\hline & $\begin{array}{c}\text { Chlorella vulgaris, } \\
\text { Scenedesmus sp, } \\
\text { etc. }\end{array}$ & $0.17-0.28$ & $16.1-21.1$ & $30.4-53.9$ & Batch $(0.25 \mathrm{~L})$ & $\begin{array}{l}\text { Rodolfi et al., } \\
2009\end{array}$ \\
\hline & Nannochloropsis sp. & 0.36 & 32.3 & 117 & $\begin{array}{l}\text { Continuous }(110 \mathrm{~L}) \\
(\text { HRT } 2.5 \mathrm{~d})\end{array}$ & $\begin{array}{l}\text { Rodolfi et al., } \\
2009\end{array}$ \\
\hline & $\begin{array}{l}\text { Chlorella } \\
\text { minutissima }\end{array}$ & 0.137 & $36-44$ & 602 & $\begin{array}{c}\text { Continuous (3 L) } \\
\text { (HRT } 3 \mathrm{~d})\end{array}$ & $\begin{array}{l}\text { Tang et al., } \\
2012\end{array}$ \\
\hline & $\begin{array}{c}\text { Synechocystis } \\
\text { aquatilis }\end{array}$ & 0.932 & 18.58 & 177.1 & $\begin{array}{c}\text { Continuous (8 L) } \\
(\text { HRT } 8.5 \mathrm{~d})\end{array}$ & $\begin{array}{c}\text { Kaiwan-arporn } \\
\text { et al., } 2012 \\
\end{array}$ \\
\hline \multirow{3}{*}{ Heterotroph } & $\begin{array}{c}\text { Chlorella } \\
\text { protothecoides }\end{array}$ & $1.7-7.4$ & $43.0-57.8$ & 732.7 - 3701.1 & Batch (5 L) & $\begin{array}{l}\text { Xiong et al., } \\
2008\end{array}$ \\
\hline & Chlorella vulgaris & $0.08-0.15$ & -36.0 & $27.0-35.0$ & Batch (1 L) & $\begin{array}{l}\text { Liang et al., } \\
2009\end{array}$ \\
\hline & $\begin{array}{c}\text { Galdieria } \\
\text { sulphuraria }\end{array}$ & $14.6-5$ & $N / A^{a}$ & $\mathrm{~N} / \mathrm{A}^{\mathrm{a}}$ & $\begin{array}{l}\text { Continuous } \\
(3 \mathrm{~L}, \text { HRT } 2 \mathrm{~d})\end{array}$ & $\begin{array}{c}\text { Graverholt and } \\
\text { Eriksen, } 2007\end{array}$ \\
\hline
\end{tabular}

${ }^{\mathrm{a}} \mathrm{N} / \mathrm{A}=$ Not attained 
Fig. 1 Schematic of membrane-coupled bioreactor system for mass cultivation of photosynthetic bacteria

Fig. 2 Daily variation of cell concentration and lactate degradation in the CFSTR at various substrate concentrations

Fig. 3 Daily variation of cell concentration and lactate degradation in the membrane-coupled bioreactor at various operating conditions

Fig. 4 Fatty acids profile of Rhodobacter sphaeroides 
Fig. 1 Schematic of membrane-coupled bioreactor system for mass cultivation of photosynthetic bacteria

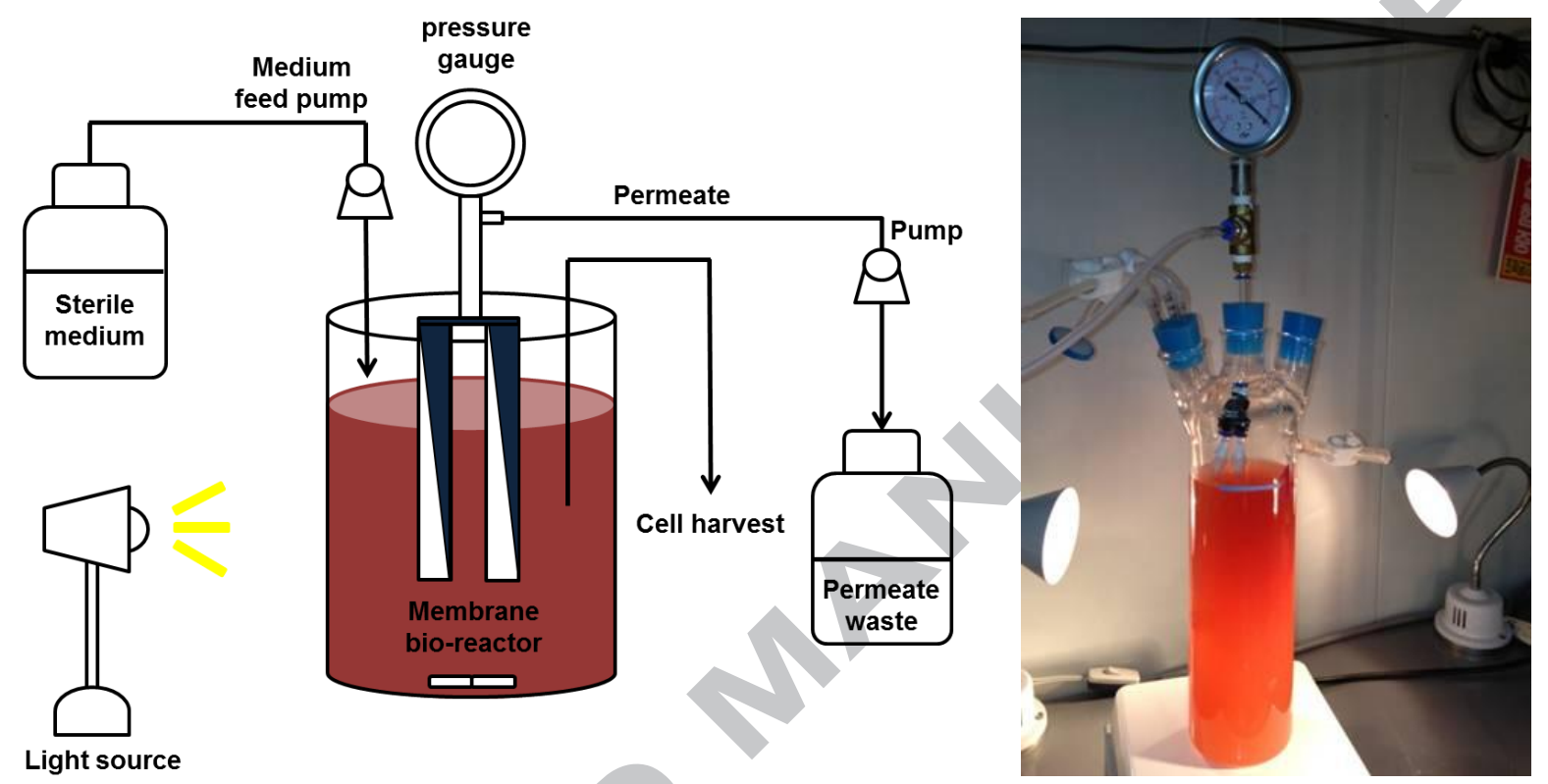


Fig. 2 Daily variation of cell concentration and lactate degradation in the CFSTR at various substrate concentrations

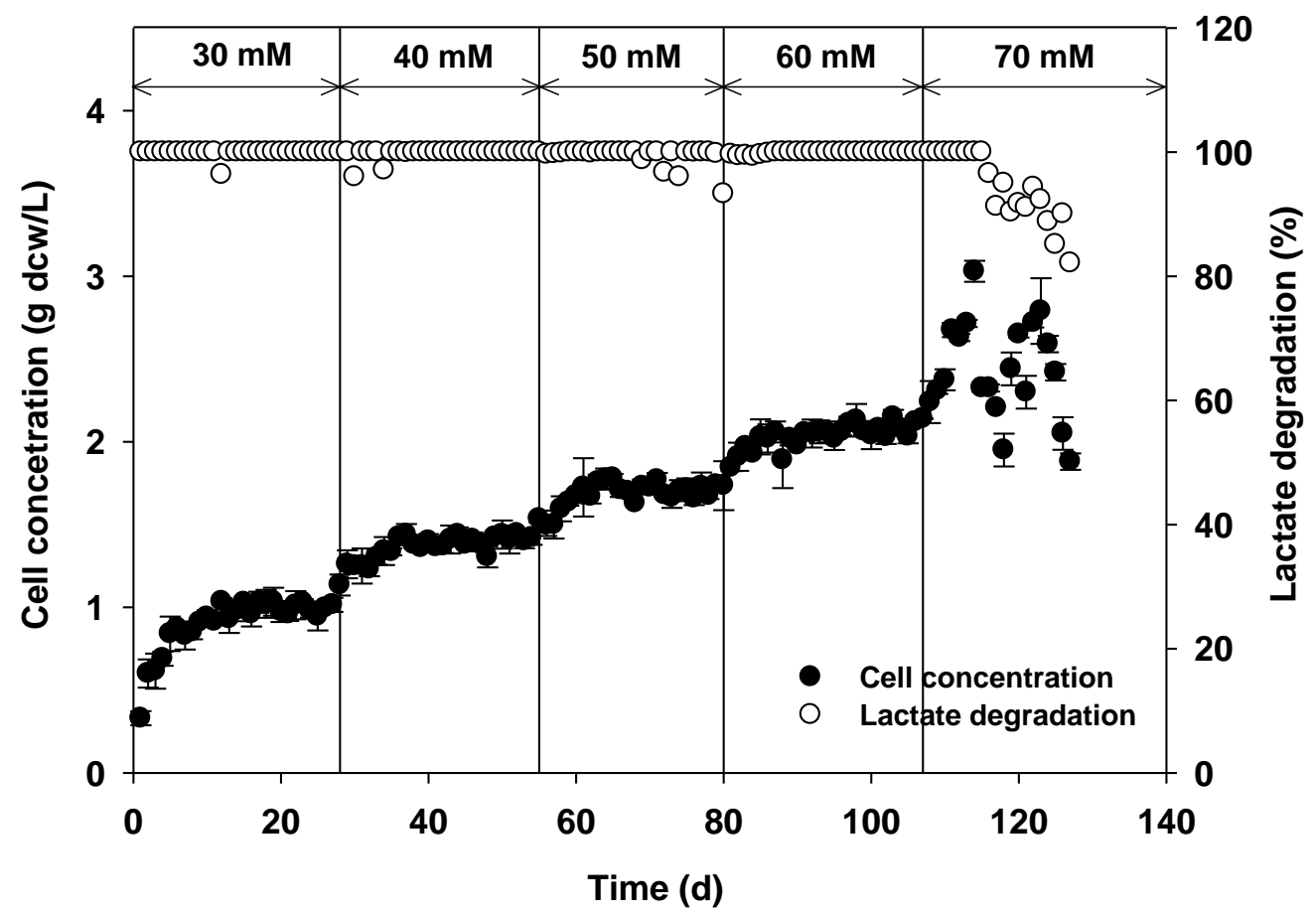


Fig. 3 Daily variation of cell concentration and lactate degradation in the membrane-coupled bioreactor at various operating conditions

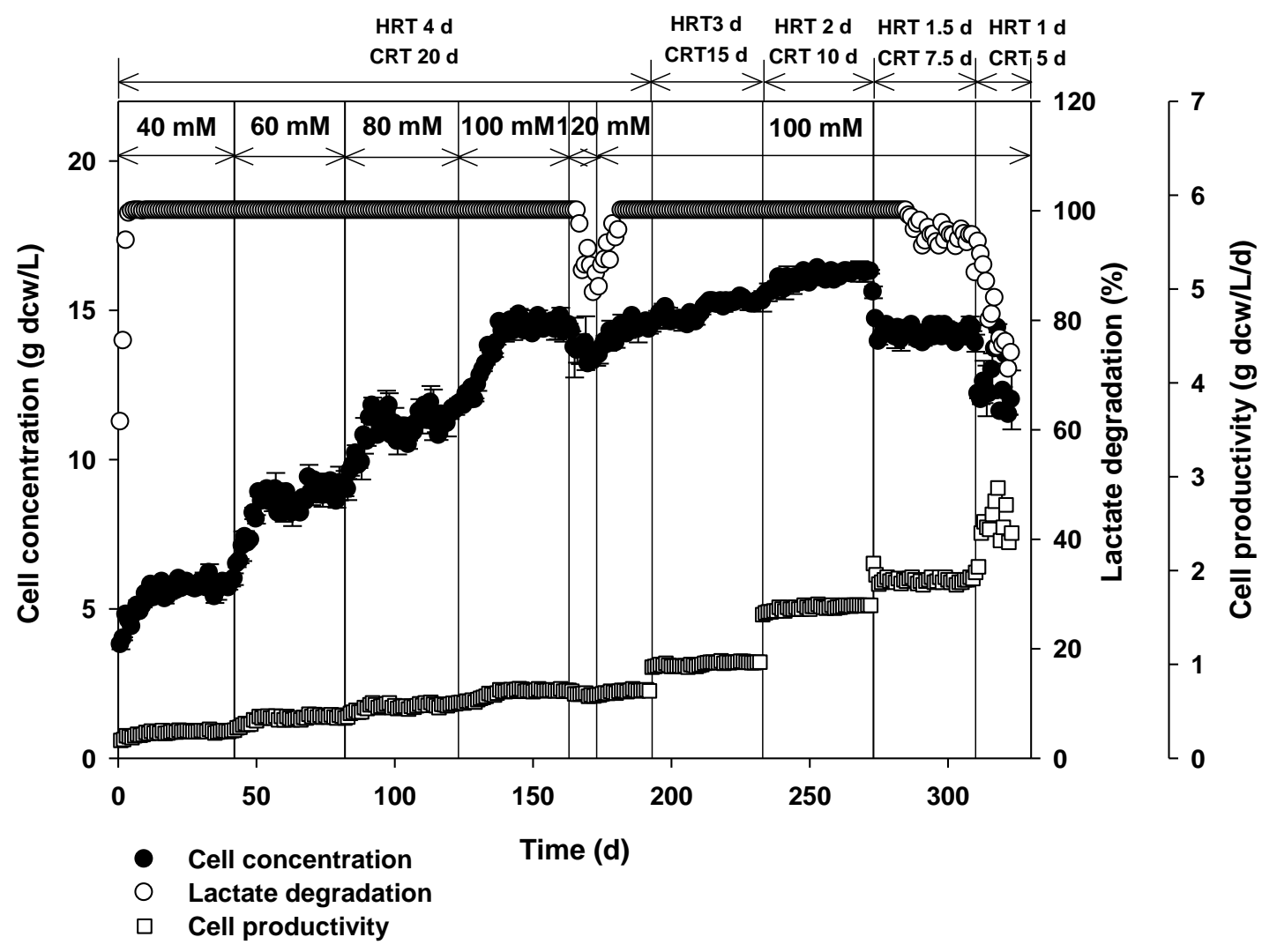


Fig. 4 Fatty acids profile of Rhodobacter sphaeroides

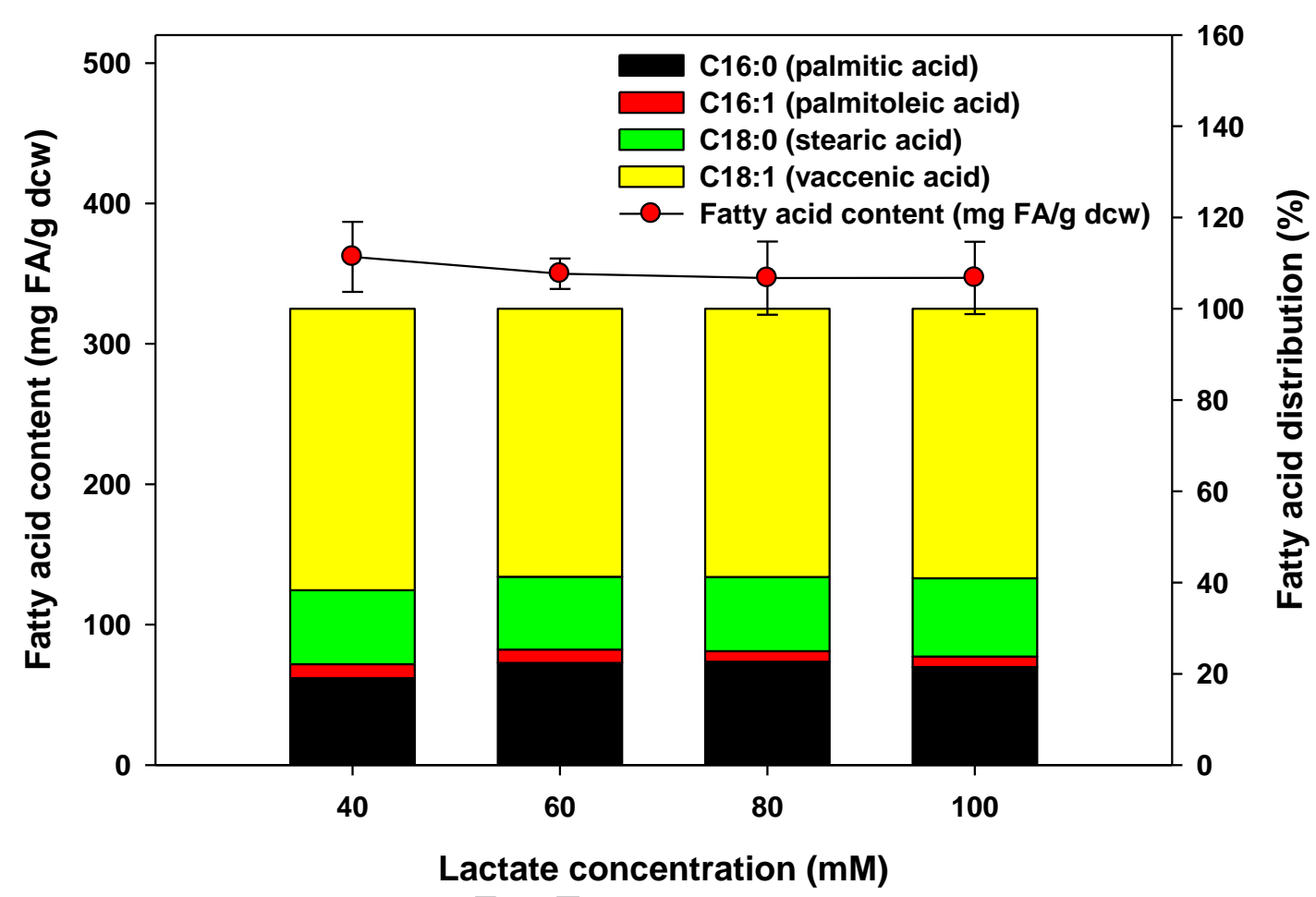




\section{Waste acids Permeate pump}

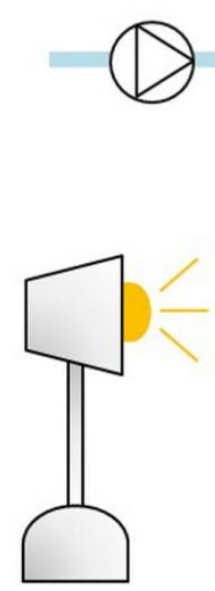

Light

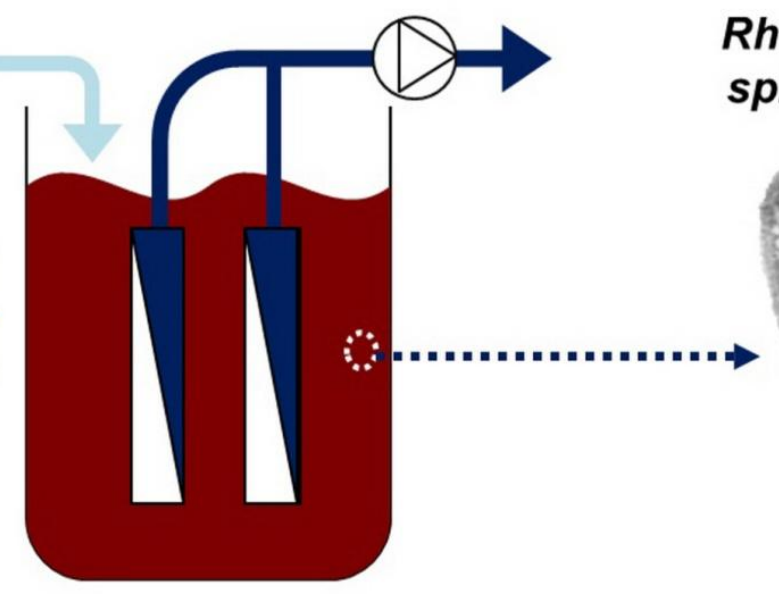

Membrane bioreactor for mass cell production
Rhodobacter

sphaeroides

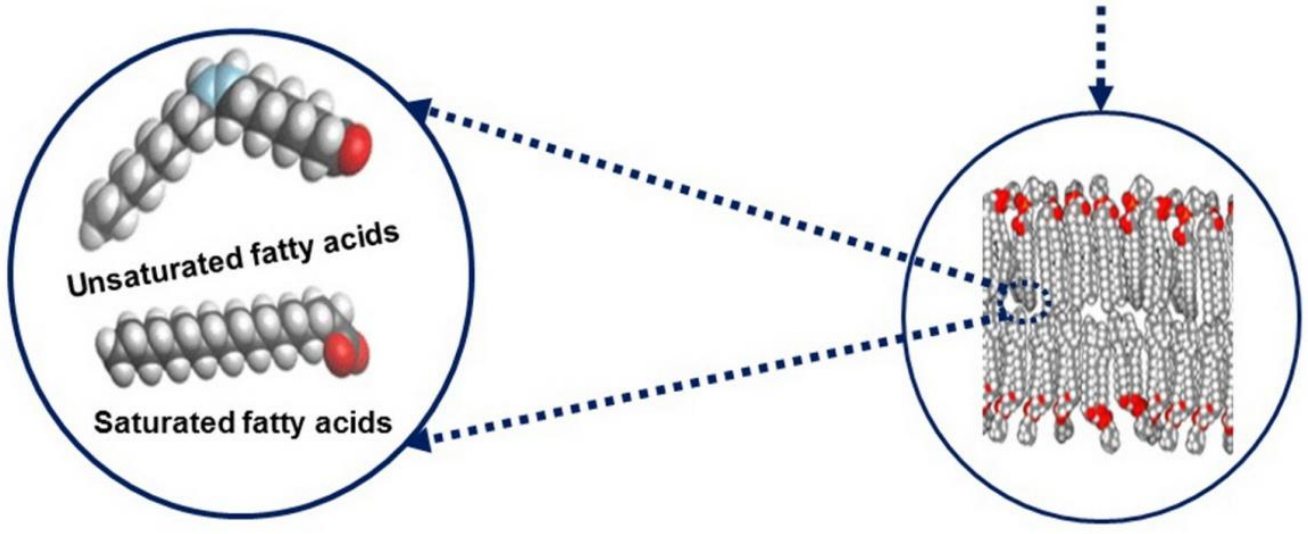




\section{Highlights}

- Photosynthetic bacteria cultivation for fatty acids (FA) production from lactate

- Continuous-flow, stirred-tank reactor and membrane-coupled bioreactor

- Maximum cell productivity of $1.9 \mathrm{~g} \mathrm{dcw} / \mathrm{L} / \mathrm{d}$ and FA productivity of $665 \mathrm{mg} \mathrm{FA} / \mathrm{L} / \mathrm{d}$ 